\title{
Yıldız Gücü (Star Power): Yıldız Sporcular Y Kuşağı Tüketicilerinin Tüketim Kararlarını Etkiler Mi?

\author{
(The Star Power: Do Star Athletes Impact Consumption Decisions of Generation Y
} Consumers?)
}

\author{
Handan ÖZDEMİR a Elif AKAGÜN ERGİN b Mustafa Serhat AVCI iD c \\ a Çankaya Üniversitesi, Halkla İlişkiler ve Reklamcılık Bölümü, Ankara, Türkiye. h ozdemir@cankaya.edu.tr, \\ b Çankaya Üniversitesi, İşletme Bölümü, Ankara, Türkiye. elifrutgers@yahoo.com, \\ c Çankaya Üniversitesi, Sosyal Bilimler Enstitüsü, Ankara, Türkiye. serhatavci13@hotmail.com
}

\begin{tabular}{|c|c|}
\hline MAKALE BİLGİSi & ÖZET \\
\hline Anahtar Kelimeler: & Amaç - Bu araştırmanın amacı, "yıldız gücü faktörleri" olarak bilinen; profesyonel güvenilirlik, \\
\hline Yıldız gücü & mpatik kişilik, atletik uzmanlık, sosyal çekicilik ve karakteristik tarz faktörlerinin $\mathrm{Y}$ kuşağ \\
\hline Atletik yıldız gücü & keticilerin genel ve spesifik tüketimleri üzerindeki etkilerini ortaya koymak ve yıldız gücü etkisinin \\
\hline Y kuşağı & cinsiyet ve yaş demografik değişkenleri ile ilişkilerini incelemektir. \\
\hline SASP ölçeği & Yöntem - Nicel araştırma yönteminin tercih edildiği bu araştırmada, Braunstein ve Zhang'ın (2005) \\
\hline Tüketim kararı & $\begin{array}{l}\text { atletik yıldız gücü üzerine yaptıkları çalışmada geliştirdikleri Athletic Star Power (SASP) ölçeği veri } \\
\text { toplama aracı olarak kullanılmıştır. Y kuşağı } 450 \text { katılımcıdan anket yöntemi ile toplanan veriler SPSS }\end{array}$ \\
\hline $\begin{array}{l}\text { Gönderilme Tarihi } 18 \text { Nisan } \\
2021\end{array}$ & $\begin{array}{l}25.0 \text { paket programı kullanılarak tasnif edilmiş, araştırmanın hipotezleri, çoklu doğrusal regresyon } \\
\text { analizi, bağımsız örneklemler için T- testi ve ANOVA analizi yöntemleri ile test edilmiştir. }\end{array}$ \\
\hline $\begin{array}{l}\text { Revizyon Tarihi } 17 \text { Haziran } \\
2021\end{array}$ & $\begin{array}{l}\text { Bulgular - Araştırma sonucunda, Y kuşağı tüketicilerin tüketim kararlarında yıldız gücü } \\
\text { faktörlerinden etkilendikleri belirlenmiştir. Araştırma sonucunda, yıldız gücü etkisinin kadın ve }\end{array}$ \\
\hline Kabul Tarihi 25 Haziran 2021 & $\begin{array}{l}\text { erkek bireyler üzerinde anlamlı bir farklılık gösterdiği görülmüş ve erkek tüketicilerin kadın } \\
\text { tüketicilere göre atletik yıldız gücünden daha fazla etkilendikleri belirlenmiştir. Buna ek olarak, }\end{array}$ \\
\hline Makale Kateg & 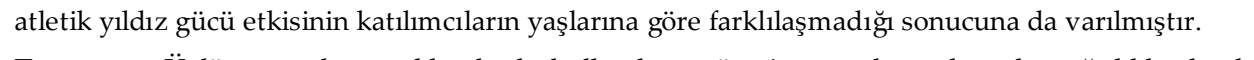 \\
\hline
\end{tabular}

Araștırma Makalesi

Tartıșma - Ünlü sporcuların reklamlarda kullanılması üzerine yapılan çalışmalar, ağırlıklı olarak reklam yöneticilerinin görüşlerine odaklanmış, tüketicilerin bakış açılarının önemini göz ardı etmiştir. Buna ek olarak, çeşitli çalışmalarda ise, ünlü sporcuların tüketiciler üzerindeki etkilerine dair bileşenlerin birbirlerinden bağımsız olarak değerlendirildiği görülmektedir. Bu noktadan hareketle bu araştırmada, yıldız gücü etkisinin tüketici açısından ele alınması hedeflenmiş ve yıldız gücü faktörleri olarak kabul edilen tüm faktörlerin, dünyanın en büyük ikinci tüketici topluluğu olarak kabul edilen $\mathrm{Y}$ kuşağı tüketicilerin tüketim kararları üzerindeki olası etkileri ortaya konmaya çalışılmıştır. Bu bağlamda, markaların ve firmaların dünya nüfusunun yaklaşık \%27'sini oluşturan ve Türkiye'de ise halen 18 milyonun üzerinde tüketiciyi kapsayan Y kuşağının, yıldız sporculardan ne derece etkilendiklerini görmeleri ve "yıldız gücü" etkisinden faydalanabilmeleri oldukça önemlidir.

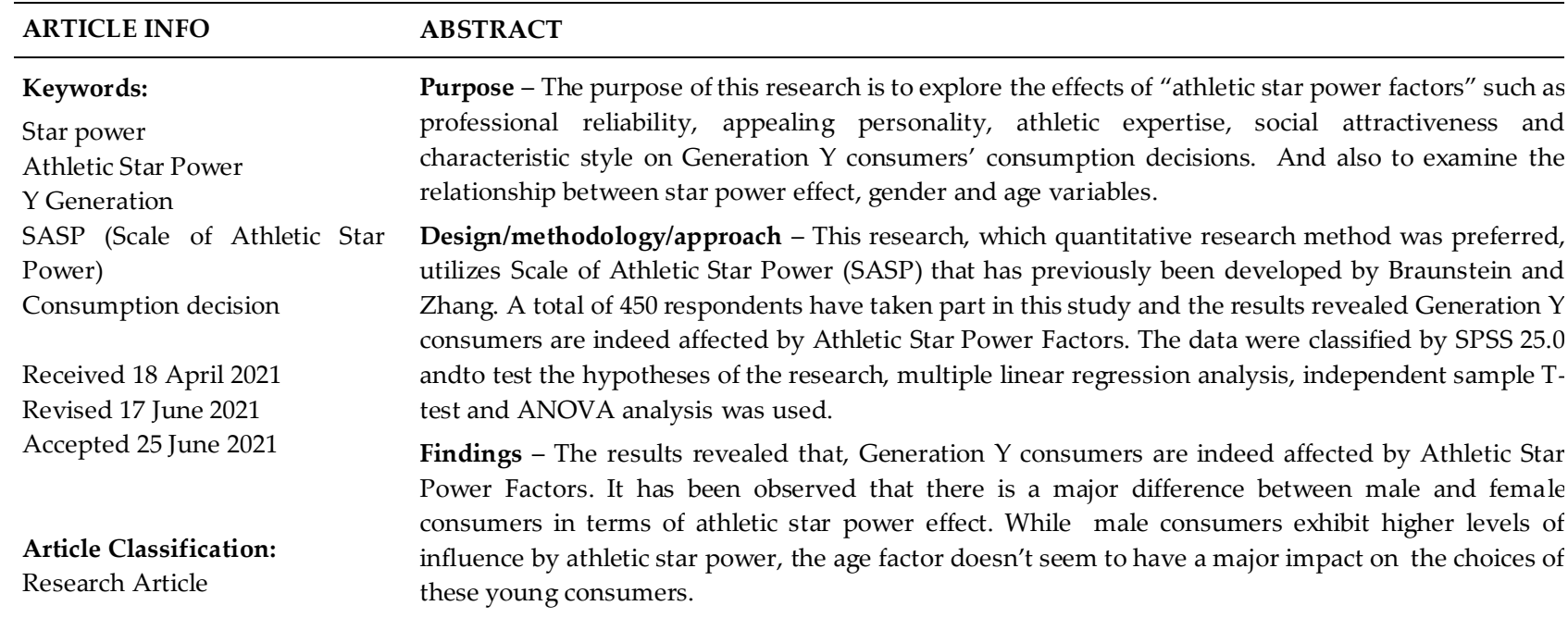

\section{Önerilen Atıf/ Suggested Citation}

Özdemir, H., Akagün Ergin, E., Avcı, M.S. (2021). Yıldız Gücü (Star Power): Yıldız Sporcular Y Kuşağı Tüketicilerinin Tüketim Kararlarını Etkiler Mi?, İ̧sletme Araştırmaları Dergisi, 13 (2), 1751-1763. 
Discussion - Studies on sports celebrities mainly focused on the opinions of advertising managers,
ignoring the importance of consumers' perspectives. In addition, in various studies, it is seen that the
components regarding the effects of famous athletes on consumers are evaluated independently. In
this research, the goal is to address the impact of star power factors from the consumer perspective.
The potential impacts of all factors on the consumption decisions of generation Y consumers, who are
considered to be the second largest consumer community in the world, have been revealed. In this
context, it is important to understand the benefits of the impact of star athlete celebrities on the
purchase decision of Generation Y consumers for both the brands and the companies.

\section{GİRIŞ}

Geçmişten günümüze müzisyenler, modeller, film yıldızları, komedyenler markalar için önemli birer tanıtım kaynağ 1 olmuştur. Markalar, pazardaki olumlu etkileri yakalamaya başladıktan sonra, bireylerin tutku ve fanatiklik düzeyinde bağlı oldukları ilgi alanlarından biri olan spora yönelmişlerdir. Sporun insanlar üzerindeki bu güçlü etkisini, insanların tüketim alışkanlıklarına yansıtmak için ünlü sporcular reklamlarda sıklıkla kullanılmaya başlanmıştır. Ünlü bir sporcu tüketiciler için bir markayı temsil eden figür olmaktan çok daha fazlasıdır. Reklamlarda kullanılan ünlü sporcular takımlarını, şehirlerini, ülkelerini ve hatta yaptıkları sporu uluslararası anlamda temsil eden birer rol modeldirler ve spor dışındaki diğer alanlarda ünlü olup, reklamlarda marka yüzü olarak kullanılan ünlülerden farklı olarak, çeşitli tüketici gruplarına doğrudan hitap edebilirler. İlgi duyulan bir spor dalı ise, insanların sosyal statüleri, yaşları, cinsiyetleri gibi çeşitli unsurlar genellikle geri planda kalmaktadır.

Sporun insanlara verdiği ilham ve inanç, markaların müşterileri üzerinde yaratmak istediği yoğun etki için çok etkili bir araç haline gelmiştir. Bu etki, bazı sporcularda spor hayatı boyunca devam edebiliyorken, bazılarında ise kısa süreli olabilmektedir. "Efsane" olarak nitelendirilen sporcuları reklamlarında kullanan markaların pazardaki yerinin çok güçlü olmasının yanı sıra, tüketicilerin gözündeki değerlerinin de diğer markalara oranla çok daha yüksek olduğu bilinmektedir.

Ünlülerin reklamlarda kullanılmasının çeşitli ortak değişkenlikleri vardır. Bu değişkenleri fiziksel çekicilik veya yıldız çekiciliği, sempatik kişilik, sosyal imaj, atletik başarı, ürün ile uyumluluk olarak sıralamak mümkündür. Mevcut literatür incelendiğinde, birçok çalışmada ünlü sporcuların tüketiciler üzerindeki etkilerine dair bileşenlerin birbirlerinden bağımsız olarak değerlendirildiği ve reklamlarda kullanılan ünlü sporcuların yukarıda sözü edilen özelliklerle tüketicileri ne ölçüde etkilediklerine dair bölgesel bir çalışmanın da eksikliği olduğu görülmektedir. Buna ek olarak; medya etkisi, ürünün özellikleri ve tüketicilerin, ürünün tanıtım sürecinde kurulan ilişkinin ayrılmaz bir parçası olması gerekir ancak daha önce yapılan birçok çalışmada bu unsurların bir bütün olarak dikkate almadığı söylemek mümkündür. Sporcu ünlülere odaklanan çalışmalar, ağırlıklı olarak reklam yöneticilerinin görüşlerine odaklanmış, tüketicilerin bakış açılarının önemini göz ardı etmiştir. Bazı araştırmacılar (McCormick, 2018), tüketicilerin ihtiyaç ve isteklerini anlamanın, istenen hedef pazarla ayn özelliklere sahip bir yıldız sporcunun seçimine yardımcı olacağını ve dolayısıyla spor yıldızlarının etkinliğini artırmaya yardımcı olacağını belirtmektedirler.

Bu noktalardan yola çıkarak, bu araştırmada, yıldız gücü etkisinin tüketici açısından ele alınması hedeflenmiş; "yıldız gücü faktörleri" olarak bilinen; profesyonel güvenilirlik, sempatik kişilik, atletik uzmanlı, sosyal çekicilik ve karakteristik tarz faktörlerinin, dünyanın en büyük ikinci tüketici topluluğu olarak kabul edilen Y kuşağı tüketicilerin genel ve spesifik tüketimleri üzerindeki olası etkilerini ortaya koymak amaçlanmış ve ek olarak, yıldız gücü etkisinin cinsiyet ve yaş demografik değişkenleri ile ilişkileri incelenmiştir.

\section{KAVRAMSAL ÇERÇEVE}

\subsection{Reklamda Ünlü Kullanımı}

Ünlülerin reklamlarda kullanılması, on dokuzuncu yüzyıla kadar uzanmakta ve akademik alanda günümüzde hala ilgi çekmektedir. Agrawal'a göre, ünlü kişi kavramıla tüketici satın alma kararları üzerinde olumlu etki yapacak bir referans grubundan bahsedilmektedir. Bu grubun içerisinde başarılı iş adamlarından sinema ve tiyatro oyuncularına, sporculardan gazetecilere kadar birçok farklı alanlarda başarı kazanmış kişiler bulunmaktadır. Televizyon reklamlarının yaklaşık \%20'sinde televizyon, spor, müzik, sinema ya da iş dünyasından ünlü ve tanınmış kişiler kullanılmaktadır. Televizyon reklamları için harcanan milyonlarca doların yaklaşık \%10'u reklamlarda kullanılan bu ünlü kişiler için kullanılmaktadır (Solak, 2016: 259). Reklamlarda ünlü kullanımı ile ilgili akademik araştırmaların çoğu, Source Credibility ve Attractiveness 


\section{H. Özdemir - E. Akagün Ergin - M. S. Avcr 13/2 (2021) 1751-1763}

modelleri alanında bağlamsallaştırılmıştır. Bu çalışmalar, ünlülerin tüketiciler üzerindeki etkilerini; uzmanlık, güvenilirlik, çekicilik, aşinalık ve sevilebilirlik gibi algılanan özellikler aracılığıyla uyguladıklarını ileri sürmektedir (Choi vd., 2005: 86). Çoğu reklamcı için, bir ürünün/markanın tanıtımında kullanılacak ünlüyü seçmek zor ve riskli bir iştir.

Yapılan çeşitli araştırmalara göre, reklama ve markaya olan tutum ile satın alma kararlarında ünlü kişiler ve sıradan kişilerin katkısı arasında belirgin farklar bulunmamaktadır. Var olan farklılıklar, mesaj alıcısının bilişsel tepkilerinde bulunmaktadır. Reklamda sıradan bir kişinin yer alması koşulunda mesaj alıcıları, markaya ve onun özelliklerine daha çok odaklanmaktadır. Ünlü kullanılması koşulunda ise alıcılar, daha çok reklamdaki ünlüye yönelmektedirler (Çam, 2016: 165). Yine farklı araştırmacılar ünlü destekçilerin, ünlü olmayan bir destekçiden daha fazla olumlu tutum ve daha fazla satın alma niyeti ürettiğini ortaya koymaktadır (Erdoğan, 1999: 294).

Markalar daha önce sadece reklam, logo ve sloganlarla yaratmaya çalıştıkları olumlu imajı, günümüzde tanıtımlarında kullandıkları ünlülerle sağlamaya çalışmaktadırlar. Ünlülerin reklamlarda kullanılmasına öncülük etmiş çeşitli markalar, elde ettikleri başarılar sayesinde pazardaki konumlarını günümüzde de koruyabilmektedirler. Marka yüzü olan sporcunun faaliyet gösterdiği spor alanındaki başarısı, markanın da başarısı olarak tüketicilere yansımakta ve alanında başarı yakalayan bir sporcu, temsil ettiği markayı da kendisiyle beraber yukarı doğru taşımaktadır.

Yıldız sporcular, spor pazarlamasının önemli bir parçası haline geldiklerinden beri, toplum için sporcu olmaktan fazlasıdırlar. Sporcular, ünlü başlığı altında tanımlanan, şöhretlerini tüketicilerle marka ve ürünleri tanıtmak için kullanan kişiler haline gelmişlerdir (McCracken, 1989: 321). 30 yıl öncesine kadar ünlüler yayınlanan reklamların en fazla dörtte birinde karşımıza çıkarken (Howard, 1979: 2), günümüzde hemen her reklamda karşılaştı̆̆ımız ünlüler, markalar için tüketicileri etkilemek amacıyla kullanılan birer strateji unsuru haline gelmişlerdir. Spor pazarlamacıları sporcuların popülerliklerini sadece spor ile alakalı ürün ve markalarda kullanmayı değil, cep telefonu, temizlik ürünleri, kişisel bakım ürünleri, otomobil gibi birçok farklı ürün kategorisinde de tercih etmektedirler.

Özellikle sporun bir gösteriye dönüştüğü günümüzde, gösterinin en iyi yayınlanabileceği yer olan televizyon dolayısıyla buna bağlı olarak televizyon reklamları da spordan fazlasıyla etkilenmiştir. Bugün gerek en popüler spor dalları (futbol, basketbol, voleybol, tenis, araba yarışları, atletizm, boks vs.) gerek ise en popüler/ünlü sporcular (Tiger Woods, David Beckham, Messi, Michael Jordan, Arda Turan vb.) televizyon reklamlarında sıklıkla boy göstermektedir (Gültekin, 2012: 63).

\subsection{Yıldız Gücü Etkisi}

Ünlü bir sporcu, "bir reklamdaki bir ürünü tavsiye etmek veya ürünü tanıtmak için kamuoyunun takdirine başvuran ünlü bir sporcu veya antrenör" olarak tanımlanabilir. Aktif olarak sporla uğraşanlara ek olarak, bu kişiler, emekli veya vefat etmiş profesyonel sporcuları da içerebilir. Tüketici satın alma kararlarını olumlu yönde etkilemeleri muhtemel olduğundan, reklamlarda ünlü kişilerin kullanılması, uzun zamandır üreticiler ve perakendeciler tarafından ürün satma çabalarında sıklıkla kullanılmaktadır (Lear vd., 2009: 308). Bir sporcunun halkın gözündeki konumu, başkalarının kendisi gibi olmayı istemesini sağlama yeteneği nedeniyle ona bu referans gücü kullanma fırsatı sunar; aynı zamanda bilgi ve becerilerinden dolayı uzmanlığı, sosyal rolü veya statüsü nedeniyle meşru bir güç vererek, olumlu duyguları ortaya çıkarma veya olumsuz duyguları da ortadan kaldırmasına fırsat verir (Renton, 2009: 44). Bazen yıldız gücü olarak da anılan şöhret gücü, Magnini ve arkadaşları'na (2010) göre, bir ünlünün başkalarını ikna etme yeteneğidir ve kısmen popülerliğe dayanır. Yazarlara göre şöhret gücü veya yıldız gücü, tanıtımı yapılan ürüne/markaya yanıt vermesi için başka bir kişiyi ikna etme yeteneği olarak tanımlanabilir. Ünlülerin temel ikna gücü popüler, ünlü, tanınabilir, hayranlık duyulan, modaya uygun ve moda olmalarından gelir. Bu özellikler, bir kişinin neden ünlü statüsüne ulaştığının ve neden başkalarını etkileme gücüne sahip olduğunun gösteren başlıca nedenleridir. Çoğu zaman, bir ünlünün sahip olduğu güç seviyesi, yıldızın göründüğü herhangi bir araç veya yarışmadan bağımsız olarak halkın algısının olduğu noktaya kadar yükselir. Bazı durumlarda ünlülerin gücü o kadar kuvvetli olabilir ki, bir ünlünün seçimi neredeyse yalnızca bireyin popülerlik düzeyine göre bile yapilabilmektedir. 


\section{H. Özdemir - E. Akagün Ergin - M. S. Avc1 13/2 (2021) 1751-1763}

Spor endüstrisi son 30 yılda tüm dünya ülkelerinde oldukça iyi bir ilerleme kaydetmiştir. Spor ile ilgili işletmelerin endüstri içinde yer alanları, sportif eşya üreten işletmeler, kitle iletişim araçları, stadyumlar gibi spor alanları, ticari eşya üreten işletmeler, oyuncular, spor takımları ve profesyonel ligler sektörün gelişim göstermesini ve çoğu sektörden pay elde etmesine katkıda bulunmuştur. Spor endüstrisinin gelişmesi spor pazarlamasının da gelişmesini de olumlu yönde etkilemiştir (Karaman vd., 2019: 2). Sporun sadece spor olmaktan çıkıp, profesyonel bir eğlence sektörü haline gelmesinden bu yana, spor pazarlamacıları bu durumdan faydalanmaya başlamışlardır. Spor dallarında 'yıldız' statüsüne ulaşmış sporcular halkın gözünde oluşan kahraman profiliyle, tanıtımı yapılan ya da yapılacak ürünlerin pazardaki konumlarını belirleyebilmektedirler. Bu durum sadece sporcular ve markalara değil, ürünü satın alıp kullanan kişilere de kendilerine sağlanan imaj nedeniyle çeşitli faydalar sağlamaktadır (Braunstein ve Zhang, 2005: 37). Markalar, ürünlerini mevcut ve potansiyel müşterilerinin zihinlerinde oluşan 'yıldız' etkisine göre konumlandırıp, marka algısını da dolaylı olarak etkileyebilmektedirler. Sporcu karakterleri ve başarıları, daha önce birçok marka tarafından ürün ve marka imajını şekillendirmek için kullanılmış, marka imajı yaratmanın yanı sıra mevcut imajlarını değiştirmek içinde zaman zaman sporcuların hem atletik hem de karakteristik özelliklerinden faydalanmışlardır.

Pazarlama araştırmacıların çoğunluğu, uygun şekilde kullanıldığında, ünlülerin marka yüzü olarak kullanılmasının, bir ürünü/markayı tanıtmak ve tüketicilerin satın alma kararlarını etkilemek için etkili bir iletişim stratejisi olabileceğini savunmaktadırlar. Seçilen bir ünlü, hedef kitle kendisini üye grubunun bir parçası olarak algıladığında (yani inançlarını ve yaşam tarzını yansıtan) etkili bir destekleyici olabilir. Bu gibi durumlarda, grup üyeleri, grup kimliklerini korumak ve güçlendirmek için genellikle tanıtımı yapılan ürünü/markayı satın alma eğilimindedir. Benzer şekilde, ünlü bir kişi, gelecekte o kişiyle ilişkilendirilmek isteyen hedef tüketiciler için istek uyandıran bir figür olarak hizmet edebilir. Bu gibi durumlarda, tanıtılan bir ürün/marka sembolik bir sinyal haline gelir ve tüketiciler en sevdikleri ünlüleri taklit etmek için bu ürünü/markayı satın alma eğilimi gösterebilirler (Yang,2018: 402). Reklamcılar, televizyon reklamlarında rol alan tanınmış kişilerin karakterleriyle tüketicilerin karakterlerinin özdeşleştirildiği takdirde, tüketicilerin reklam içerisine dalmış gibi hissetme duygusunun büyük ölçüde artacağını, böylelikle tanınmış kişinin kullanmış olduğu ürün veya hizmeti benimseme ihtimalinin de artış göstereceğini tahmin etmektedirler. Bu perspektifte reklamı izleyen kişi de, karşısındaki ünlü kişiyi kendisiyle özdeştirdiği zaman onun tutum ve davranışların benimsemeye daha yatkın olmaya yönelmektedir yani kendisi ile özdeşleştirdiği ünlünün kullandığı ürün veya hizmeti tüketmeye başlamaktadır denilebilir (Solak, 2016: 263).

Gerek sportif faaliyetlerin gerekse sporla ilgili ürünlerin tüketimi üzerine yapılan çalışmalarda da "yıldız gücü" faktörünün çeşitli araştırmacılar tarafından önemli bir faktör olarak kabul edildiği görülmektedir (Bennett ve Henson, 2003; Thomaselli, 2008; Dix vd., 2010; Lewis ve Yoon, 2018; James ve Ridinger, 2002; Li vd., 2019; Khabiri vd., 2017). Örneğin, Dugalić ve Lazarević (2016), ünlülerin satın alma kararları üzerinde etkisi olan ana faaliyetlerini (spor, eğlence/medya, moda veya kültür) belirlemek için 314 katılımcı ile geçekleştirdikleri çalışmalarında, ünlü sporcuların tanıtımı yapılan ürünün satın alınmasına doğrudan etki ettiği ve ve katılımcıların markayı tanımlamalarına yardımcı olduğunu ortaya koymuşlardır. Bush vd. (2014) ise, atlet rol modellerinin gençlerin satın alma niyetleri ve davranışları üzerindeki etkisini inceledikleri çalışmalarında ünlü sporcuların, Y kuşağı tüketicilerin olumlu ağızdan ağıza iletişim ve marka sadakatleri üzerinde olumlu bir etkisi olduğunu belirlemişlerdir. Genel olarak, yapılan çalışmaların çoğunda, yıldız gücünün tüketicilerin satın alma davranışları üzerinde olumlu bir etkiye sahip olduğu görülmektedir.

Sporcular yıldız haline geldikçe yüzleri, isimleri ve benzerlikleri genellikle çok sayıda ürünle ilişkilendirilir. Reklam endüstrisi, yıldız bir sporcuyla bağlantılı olabileceğine inandıkları herhangi bir ürünün ünlü sporcular tarafından tanıtılmasını sağlayarak, tüketicilerin Amerikan şöhret takıntısından sıklıkla faydalanmaktadır. Bu noktada, bir sporcunun bir ürünle benzersiz bağlantısı, yöneticilerin ürünlerini, şirketlerinin algılanan imajına en uygun yıldızla eşleştirmesine neden olan bir reaksiyon yaratmaktadır (Braunstein ve Zhang, 2005: 39). Ünlü sporcuların tanıtım yüzü olarak kullanılmasının çeşitli markalara büyük karlar sağladığı bilinmektedir. Örneğin, tüketicilerin "efsane" olarak anılan ünlü basketbol yıldızı Michale Jordan'ın ismini taşıyan ayakkabı ve formalara sahip olabilmek için yaklaşık 7,3 milyar dolar para harcadıkları bilinmektedir (Janoff, 2004; 20). Buna ek olarak, Nike markası halihazırda NFL ile tüm takımlardaki oyuncuları giydirmek için beş yıllık, yaklaşık 1,1 milyar dolarlık bir sponsorluk anlaşması imzalamıştır ve bu durum, pazar paylarını genişletmeye ve spor giyim pazarındaki küresel lider konumunu sağlamlaştırmaya yardımcı olmaktadır. Ayrıca, Nike 


\section{H. Özdemir - E. Akagün Ergin - M. S. Avc1 13/2 (2021) 1751-1763}

Pazarlama Bilimi Enstitüsü, şirketin Tiger Woods ile yaptı̆̆ı tanıtım anlaşması nedeniyle karının 2000'den 2010'a kadar 103 milyon dolar artırdığını belirten bir çalışma yayınlamıştır (Woods, 2017).

Spor dünyası içerisinde başarılı olan sporcuların ulusal veya uluslararası tanınmışlığı ve onlara duyulan güven, sporla doğrudan ilgili olsun ya da olmasın birçok şirket ürününün pazarlanmasında kullanılmaktadır. Toplumların çok önemli bölümünün ilgiyle izlediği ve takip ettiği spor olayları, imajı, birçok reklamcı tarafından reklama ve dolayısıyla ürüne olan ilgiyi arttıracak bir etken olarak kullanılmaktadır (Katırcı ve Yüce, 2016: 129).

\subsection{Yıldız Gücü ve Y Kuşağ1}

“Milenyum Kuşağı" olarak da adlandırılan ve 1980-2000 yılları arasında doğan Y kuşağı, keyfi olarak elden çıkarabilecek gelire sahip dünyanın en büyük ikinci tüketici topluluğudur. Bu kuşak aynı zamanda, ailelerinin ve yaşıtlarının satın alma kararları üzerinde güçlü bir baskı uygulayarak hem doğrudan hem de dolaylı satın alma gücü üzerinde hakimdirler. Y kuşağı üyeleri alışverişi, kendilerini tanımlayan ve kişiliklerini ifade eden bilinçli bir tüketim olgusu olarak algılarlar. Bu kuşağın üyeleri, alışveriş yaparken satın aldıkları ürünlerle ilgili yenilik ve prestij özelliklerinden faydalanmayı arzular (Kaur ve Anand, 2018: 382). Diğer kuşaklarla karşılaştırıldığında $\mathrm{Y}$ kuşağı tüketicileri, davranışlarında çeşitli tutarsızlıklar sergilemekte, bu durum da markaları, yenilikçi olmaları ve bu kazançlı tüketici segmentini etkilemek için kuşak üyelerinin tutumlarını anlama ve ihtiyaçlarını doyurmak için yeni yollar bulma konusunda teşvik etmektedir (Valaei ve Nikhashemi, 2017: 523).

Y kuşağı, ürün/marka tanıtımlarında ünlü sporcuları kullanmak isteyen markalar için çok önemli kabul edilen bir tüketici grubudur (Rein, 1997: 71). Dünya nüfusunun yaklaşık \%27'sini oluşturan Y kuşağı, markalar için ciddi bir potansiyel oluşturmakla birlikte, Türkiye' de ise Y kuşağının halen 18 milyon üzerinde nüfusu vardır (Kuyucu, 2017: 851). Toplumun şu anki ve gelecekteki kararlarını verecek olan bu yaş grubunun bireyleri, pazarlamacıların gelecekteki alıcılara yönelik odak noktasını oluşturmaktadır (Holton, 2000: 33). Firmalar için vazgeçilmez bir pazar bölümü olmasının yanında Y kuşağı, etnik ve sosyal olarak farklı, hayatlarının çeşitli aşamalarında farklı ilgi alanlarına sahip, değişen eğitim düzeyleri olan ve satın aldıkları ürünlerle ilgili çeşitli beklentileri olan bir nesildir. Genel anlamda birey kavramına dayanarak yetiştirilen Y kuşă̆ı, bireysel sporların bu nesiller için ana akım haline gelmesine sebep olmuştur. Birçok şirketin hedefi, Y kuşağ 1 tüketicilerinin ünlü sporculara gösterdiği sadakati kendi markalarına da gösterecek hale getirmektir (Braunstein ve Zhang, 2005: 41).

Y kuşağı bireyleri, son derece bağımsız, ırksal ve etnik olarak çeşitli ve sofistikedirler. Giyim, takı, yiyecek ve atıştırmalıklar ile kişisel bakım harcamaları üzerinde baskın bir etkiye sahip oldukları görülmektedir. Bu nüfus segmenti, evde oturarak ve okula giderek bir meslek edinebilen ve bu durumdan kaynaklı oluşan ciddi bir harcanabilir gelire sahip olan bireylerden oluşmaktadır. Y kuşağı önemli ölçüde birbirlerinden etkilenen ve satın alma alışkanlıklarını etkileyen bir kuşak olduğu için, uzun yıllardır ticari şirketler tarafından hedeflenen bir pazar haline gelmişlerdir (Marlatt, 1999: 40). Zamanlarının büyük bir kısmını televizyon ve internet karşısında geçiren Y kuşağı bireyleri, hayranlık duydukları ünlü sporcular gibi olmak için zaman zaman onları taklit etmeye eğilimi gösterirler. Günlük yaşantılarında onlar gibi giyinmeye çalışır, onların kullandığı markaları satın alıp ve kullanmayı tercih ederler. Bu durum, markalar için pazarda önemli bir rekabet avantajı yaratabilmektedir. Bu nedenle markalar genellikle, tüketiciler tarafından en çok beğenilen sporcuları marka bünyesine katarak, onların karizmalarından ve başarılarından faydalanırlar. Aktif olarak spor yapan ya da emekli olmuş efsane sporcular hala bu kuşak için birer rol model halindedirler.

Nüfusun Y kuşağı bölümü, teknoloji, bireysellik, yaratıcılık, risk alma ve duyu arayışında yüksek pazar duyarlılı̆̆ 1 ve sosyal bilince sahiptirler (Bennet, 2003: 105). Markaların, yıldız gücünün $Y$ kuşağ1 tüketim kararları ve davranışları üzerindeki spesifik etkisinin farkında olmaları gerekmektedir. Marka yüzü olan yıldız sporcular ve müşterileri arasında doğru bir şekilde kurulacak olan bağ, müşteri-yıldız sadakatinin markaya yansımasını da sağlar. Bu tarz bir sadakatin daha önce markalar tarafından, Michael Jordan, Lebron James ve Tiger Woods gibi yıldız sporcular aracılığıyla oluşturulduğu bilinmektedir (Braunstein ve Zhang, 2005: 43). 


\section{YÖNTEM}

\subsection{Araştırmanın Hipotezleri}

Günümüzde birçok işletme, ürünlerini veya markalarını spordaki en güçlü isimlerle ilişkilendirmek için her yıl milyonlarca dolarlık anlaşmalar yapmaktadırlar. Birçoğu, ünlü sporcuların ünlerinin ve popülaritesinin markalara fayda sağlayacağına, olumlu algılar yaratacağına, marka bilinirliğine katkıda bulunacağına ve en sıradan ürünler için bile anlam yaratacağına inanmaktadır (Dix vd., 2010). Belirli sporlarda bireysel 'yıldızlara' vurgu yapmak, takım/spor markalı ürünlerin ve belirli bir spor yıldızı tarafından tanıtılan ürünlerin satışlarını artırmaya yönelik olarak kullanılan köklü bir stratejidir. Modern çağda, atletik performansın ötesine geçen bir spor yıldızı olmanın sporcu için ticarileştirilmiş bir yükü vardır ve bu spor yıldızı literatüründe ayrıntılı olarak tartışılmaktadır. (Rahman, 2011: 150).

Araştırmacılar günümüze kadar, bir ünlünün gücünü ve etkisini belirlemeye yardımcı olmak amacıyla çeşitli teorik modeller geliştirmişlerdir. Bu teorik modellerin, yıldız gücünün oluşumunda da kullanıldığ1 görülmektedir. En iyi bilinen dört teorik model; "The Source Credibility Model, The Source Attractiveness Model, The Meaning Transfer Model ve The Match-Up Hypothesis" olarak karşımıza çıkmaktadır. Erdoğan'a (1999) göre, Source Credibility Model ve Source Attractiveness Model başlangıçta iletişim çalışmaları için geliştirilmiş olsalar da ünlü kullanımı sürecine de uygulanmıştır. Braunstein ve Zhang (2005), bu teorilerden yola çıkarak SASP (Athletic Star Power) adını verdikleri bir ölçek geliştirmişler ve yıldız gücünün bu modellerin bir kombinasyonu olduğunu savunmuşlardır. SASP'ın gelişimi, güvenilirlik, beğenilirlik, uzmanlık ve çekiciliğe odaklanan marka yüzü olan ünlü kişiler üzerinde yapılan araştırma bulguları tarafından yönlendirilmiştir. İlk faktör olan profesyonel güvenilirlik, marka yüzü olan ünlünün içtenliği ve bütünlügü olarak tanımlanmıştır. İkinci faktör ise, sevilen kişilik veya davranışının bir sonucu olarak bir ünlüye duyulan sevgi, tüketicinin marka yüzü olan ünlüyü gerçek bir birey olarak algılamasıyla ilgilidir. Üçüncü faktör, atletik uzmanlı, markayı onaylayan ünlünün güvenilir bir kaynak olduğu algısı, bir ürünü onaylamak için seçilen kişinin seçtiği alanda bilgi, deneyim ve yetenek temeline sahip olduğu algısına işaret etmektedir. Sosyal çekicilik veya bir bireyin algılanan imajı, sadece marka yüzü olan ünlünün fiziksel çekiciliğiyle ile ilgili değildir. Bunun yerine kişilik, maruz kalma ve bireyin toplumsal imajından oluşmaktadır. SASP, marka yüzü olan sporculara özgü olabilecek özellikleri kapsayacak şekilde literatürü genişletmiştir. Çalışma, beş faktörün de yıldızlar tarafından tanıtılan ürünlerin tüketimini doğrudan etkilediğini göstermiştir (Braunstein, 2006: 38). Bu noktadan hareketle, atletik yıldız gücü faktörleri olan; profesyonel güvenilirlik, sempatik kişilik, atletik uzmanlık, sosyal çekicilik ve karakteristik tarz faktörlerinin Y kuşağı tüketicilerin genel ve spesifik tüketimleri üzerindeki olası etkilerini ölçmek amacıyla aşağıdaki iki ana hipotez geliştirilmiştir.

\section{H1: Atletik yıldız gü̈ü faktörleri Y kuşağı tüketicilerin genel tüketimlerini olumlu etkiler.}

$\mathrm{Bu}$ çalışmanın ana çıktısı olarak tüketicilerin tüketim kararları seçilmiştir. Tüketim kararı, tüketici davranışları açısından en önemli ölçümlerden birisi olarak araştırmacılar tarafından sıklıkla tercih edilmektedir. Braunstein ve Zhang (2005) çalışmalarında, tüketim faktörleri olarak 2 grup tüketim değişkeni belirlemişlerdir (genel tüketim ve spesifik tüketim). Genel tüketim faktörleri; etkinlik tüketimi ve ürün tüketimini kapsarken, spesifik tüketim de; değer arttırma, medya tüketimi ve yıldız bilinirliği unsurlarını içine almaktadır. Khabiri vd. (2017), İranlı ünlü sporcuların tüketicilerin tutumları ve satın alma niyetleri üzerindeki etkisini belirlemek amacıyla yaptıkları çalışmalarında; spor ve sporcu tanımlama, algılanan değer, Yıldız gücü (SASP), ürün-ünlü eşleşmesi ve satın alma niyeti ölçeklerini kullanarak, yıldız gücünün tüm bileşenleri ile tüketicilerin tutum ve satın alma niyeti arasında önemli bir ilişki olduğunu ortaya koymuşlardır. Buna ek olarak araştırmacılar, bağımlı değişkendeki (ürüne yönelik tutum) varyasyonların \%22'sinin çekicilik ve bağımlılıkla ilişkili olduğunu ve ayrıca bağımlı değişkendeki (satın alma niyeti) varyasyonların \%16'sının çekicilik, bağımlılık, sevimli kişilik ve uzmanlıkla ilişkili olduğunu belirlemişlerdir.

\section{H2: Atletik yıldız gücü faktörleri Y kuşağı tüketicilerin spesifik tüketimlerini olumlu etkiler.}

Spor pazarlaması bağlamında, bazı araştırmalar, erkeklerin ve kadınların bilgiyi farklı şekillerde algıladığını ve işlediğini göstermektedir; cinsiyet, ürünün algılanan kalitesini etkiler ve bu da tüketicinin satın alma niyetini etkiler. Erkeklerin bir spor etkinliğinin sponsor markasını kullanma olasıllğı daha yüksektir ve ünlü sporcular tarafından tanıtılan ürünleri satın alma konusunda kadınlardan daha fazla etkilenmektedirler. 


\section{H. Özdemir - E. Akagün Ergin - M. S. Avc1 13/2 (2021) 1751-1763}

Bununla birlikte, kadın tüketiciler, en sevdikleri sporcuların desteklediği bir marka veya ürün hakkında daha olumlu görüş bildirmektedirler. Cinsiyet tüketicilerin satın alma niyetini etkileyen önemli bir unsurdur (Dusenberg vd., 2016: 5). Braunstein ve Zhang'a (2005) göre, Y kuşağ1 tüketicileri, spor ve sporla ilgili ürünlerin tercihlerinde ve tüketimlerinde farklılık gösterirler ve bu farklılıklar özellikle yaş, cinsiyet gibi farklı sosyodemografik geçmişlere sahip bireyler arasında belirgindir. Sosyodemografik değişkenler ile yıldız sporcu nitelikleri arasındaki ilişkileri incelerken, bireyler arasındaki bu büyük farklılıklar dikkate alınmalıdır. Yazarlar çalışmalarında, cinsiyet farklılıklarını incelemiş ve cinsiyet farklılıkları dikkate alındığında, marka yüzü olan sporcuların çekicilik ve uzmanlık açısından kadın katılımcılar üzerinde daha etkili olduğunu belirlemişlerdir.

\section{H3: Atletik yıldız gücü etkisi cinsiyetlere göre anlamlı bir farkllık gösterir.}

Buna ek olarak, Bush vd.'e (2005) göre, genç kadınlar sporu eğlenceli olarak görürler. Sporun sosyal yönüne değer verirler ve bu nedenle sosyal sorumluluğa sahip işletmelerin ürettiği ve favori sporcular tarafından tanıtılan spor malzemelerini satın almayı tercih ederler. Bush vd. (2004), bir diğer çalışmalarında, ünlü sporcuların Y kuşağı tüketicilerin tüketim kararları ve marka sadakati üzerinde olumlu bir etkiye sahip olduğu sonucuna varmışlar, buna ek olarak; Y Kuşağının erkek ve kadın üyeleri arasındaki farklılıklara dair bakış açılarını ortaya koymuşlardır. Örneğin ünlü sporcuların, kadınları belirli markaları satın almaları konusunda erkeklerden daha fazla etkilediği sonucuna varmışlardır.

H4: Atletik yıldız gücü etkisi yaş gruplarnna göre anlamlı bir farklılık gösterir.

\subsection{Evren ve Örneklem}

Türkiye nüfusunda yaklaşı \%35'lik bir bölümünün Y kuşağı tüketicilerinden oluşması ve Türkiye'de Y kuşağını \%59'luk kesiminin ekonomik özgürlüğe sahip olması nedeniyle (www2.deloitte.com), bu araştırmada Y kuşağı tüketicileri tercih edilmiştir. Araştırmanın evreni, Y kuşağı olarak kabul edilen 18-38 yaş arası tüketicilerden oluşmaktadır. Ülkemizde ortalama olarak 24 milyon tüketici bu yaş aralığındadır. Araştırmada $\% 95$ güven düzeyinde, $\pm \% 5$ hata payı ile çalışmak hedeflenmiş ve yapılan hesaplama sonucunda örneklem minimum 385 kişi olarak belirlenmiştir (Sencer, 1989: 399). Bu amaçla 450 adet anket, 2019 yılının Kasım-Aralık aylarında, Ankara ve Malatya illerinde, basit tesadüfi örnekleme yöntemiyle seçilen katılımcılara Ankara' da yüzölçümü göre $\mathrm{m}^{2}$ bazında en büyük alışveriş merkezi olan Ankamall'de (107. 000 $\mathrm{m}^{2}$ ), Malatya'da ise Malatya Park AVM'de yüz yüze görüşme yöntemi ile uygulanmış ve 450 anketin tamamı çalışmaya dahil edilmiştir.

Anketler uygulanırken, katılımcılardan en çok sevdikleri ve saygı duydukları bir ünlü sporcuyu düşünerek soruları yanıtlamaları istenmiştir. Literatürdeki diğer çalışmalarda, spesifik bir ünlü sporcu belirlenmiş ve kullanılmış olmasına rağmen, bu çalışmada seçim katılımcılara bırakılmıştır.

Analize başlamadan önce, verilerin normal dağılıp dağılmadığını saptamak amacıyla Shapiro-Wilk dağılım normali testi yapılmış, elde edilen değere göre (sig>.05), verilerin çalışma evreninde normal dağılım gösterdiği saptanmış ve parametrik analiz yöntemlerinin uygulanmasına karar verilmiştir.

\subsection{Veri Toplama Aracı}

Nicel bir çalışma olması ve örneklem büyüklüğü değerlendirildiğinde, bu çalışmada veri toplama yöntemi olarak 'anket yöntemi' tercih edilmiştir. Bu amaçla, Braunstein ve Zhang'ın (2005) atletik yıldız gücü üzerine yaptıkları çalışma örnek olarak alınmış ve geliştirdikleri ölçek bu çalışmada veri toplama aracı olarak kullanılmıştır. Yazarlar, yıldız gücünün belirleyici faktörlerini ortaya koymak amacıyla yaptıkları araştırmalarında, yıldız gücünü en iyi açıklayan dört ana teoriyi baz almış (Source Credibility Model, Source Attractiveness Model, Meaning Transfer Model ve Product Match-Up Hypothesis) ve bu teorilerden yola çıkarak bir ölçek geliştirmişler ve ölçeği Athletic Star Power (SASP) ölçeği olarak adlandırmışlardır. Yıldız gücünün bu modellerin bir kombinasyonu olduğunu savunan yazarlar, spor alanında en uygulanabilir modeller olması nedeniyle, Product Match-Up hariç diğer üç modeli tercih etmişler, mevcut literatürü detaylı bir şekilde inceleyerek ölçeği formüle etmişlerdir. Modeller kullanılarak uygulanan faktör analizi sonucunda yazarlar, atletik yıldız gücü faktörleri olarak 5 temel faktör belirlemişler ve bu faktörleri; F1: Profesyonel güvenilirlik, F2: Sempatik kişilik, F3: Atletik uzmanlık, F4: Sosyal çekicilik ve F5: Karakteristik tarz olarak adlandırmışlardır. 


\section{H. Özdemir - E. Akagün Ergin - M. S. Avc1 13/2 (2021) 1751-1763}

Veri toplamak için kullanılan anket üç temel bölümden oluşturulmuştur. Birinci bölümde; en sevilen spor dallarının ve en sevilen/saygı duyulan ünlü antrenör/teknik adam/ sporcuların sıralandığı iki hazırlama sorusu yer alırken, ikinci bölümde yazarların ölçeğine göre düzenlenen ve 5 'li Likert türünde (1:Kesinlikle Katılmıyorum...5:Kesinlikle Katıllyorum) hazırlanmış (profesyonel güvenilirlik faktörü için 11, sempatik kişilik faktörü için 12, atletik uzmanlık faktörü için 8 , sosyal çekicilik faktörü için 6 ve karakteristik tarz faktörü için 3 soru; genel spor tüketimi için 12 ve özel spor tüketimi için 19 soru) toplam 71 soru bulunmaktadır. Son bölümde ise deneklerin cinsiyet ve yaşlarını belirlemeye yönelik demografik sorular kullanılmıştır.

Araştırmada kullanılan ölçeğin güvenilirliğini test etmek amacıyla Cronbach Alpha analizi kullanılmış, önce faktörler ayrı olarak analiz edilmiş, sonrasında ölçeğin geneline güvenilirlik analizi yapılmıştır. Elde edilen değere göre Alpha katsayıları; profesyonel güvenilirlik faktörü için 0,937; sempatik kişilik faktörü için 0,915; atletik uzmanlık faktörü için 0,873; sosyal çekicilik faktörü için 0,816 ; karakteristik tarz faktörü için 0,623; genel spor tüketimi için 0,909 ve özel spor tüketimi için 0,933; son olarak ölçeğin genel Alpha katsayısı ise 0,969 olarak hesaplanmış ve kullanılan ölçeğin yüksek derecede güvenilir olduğu sonucuna varılmıştır.

Hipotez testlerinde, çoklu doğrusal regresyon, bağımsız örneklemler için T- testi ve ANOVA analizi yöntemleri kullanılmıştır. Bu çalışmada elde edilen veriler, SPSS 25.0 paket programı yoluyla tasnif edilmiştir.

\section{Verilerinin Analizi ve Bulgular}

\subsection{Katılımcıların Demografik Profillere Göre Dağılımı}

Katılımcıların demografik profilleri incelendiğinde, katılımcıların \%40’ının kadın, \% $60^{\prime} ı n ı n$ ise erkek tüketicilerden oluştuğu ve \%31,3’lük kesiminin 18-22 yaş grubunda yer aldığ görülmektedir. Gelir düzeylerine göre dağılıma bakıldığında ise, katılımcıların büyük çoğunluğunun (\%41,3) 500-1499TL gelir grubunda yer aldığı belirlenmiştir.

Tablo 1. Katılımcıların Demografik Profillere Göre Dağılımı

\begin{tabular}{lcclcc}
\hline Cinsiyet & Frekans & $\mathbf{\%}$ & Gelir Düzeyleri & Frekans & \% \\
\hline Kadın & 180 & 40 & $\mathbf{5 0 0 - 1 4 9 9 T L}$ & 186 & 41,3 \\
Erkek & 270 & 60 & $\mathbf{1 5 0 0 - 2 4 9 9 T L}$ & 96 & 21,3 \\
Yaş Grupları & & & $\mathbf{2 5 0 0 - 3 4 9 9 T L}$ & 57 & 12,7 \\
$\mathbf{1 8 - 2 2}$ & 141 & 31,3 & $\mathbf{3 5 0 0 - 4 9 9 9 T L}$ & 44 & 9,8 \\
$\mathbf{2 3 - 2 7}$ & 108 & 24,0 & $\mathbf{5 0 0 0 - 6 9 9 9 T L}$ & 35 & 7,8 \\
$\mathbf{2 8 - 3 2}$ & 97 & 21,6 & $\mathbf{7 0 0 0 T L}$ ve üzeri & 32 & 7,1 \\
$\mathbf{3 3 - 3 7}$ & 104 & 23,1 & & & \\
\hline
\end{tabular}

Tablo 2'de katılımcıların en sevdikleri spor dallarına göre sıralamalar yer almaktadır. Araştırmaya katılan katılımcıların yaptıkları sıralamalara göre, \%33,1'i futbolu en sevdikleri spor dalı olarak belirtirken, futbolu sirasiyla voleybol $(\% 19,6)$ ve basketbol $(\% 16,2)$ izlemektedir.

Tablo 2. En Sevilen Spor Dallarına Göre Sıralama

\begin{tabular}{cc}
\hline Spor Dalları & $\%$ \\
\hline Futbol & 33,1 \\
Voleybol & 19,6 \\
Basketbol & 16,2 \\
\hline
\end{tabular}

Katılımcılardan “En sevdikleri ve saygı duydukları ünlü antrenör/teknik adam/ sporcu'lardan” ilk üç tanesini sıralamaları istenmiş ve sonuçlar tablo 3'te verilmiştir. Bu değerlendirmeye göre, katılımcıların en sevdikleri ve saygı duydukları kişilerde ilk sırayı Fatih Terim'in aldığı görülmektedir $(\% 21,5)$. Cristiano Ronaldo $(\% 7,8)$ ikinci sırada yer alırken, katılımcıların en sevdikleri üçüncü sporcu olarak Lionel Messi (\%6)'yi seçtikleri görülmektedir. Genel olarak bakıldığında katılımcıların, en sevdikleri ve saygı duydukları ünlü antrenör/teknik adam/ sporcularda sıralamaya çoğunlukla futbolcular ve teknik adamları koydukları gözlenmiştir. Katılımcıların en sevdikleri spor dalında futbolu ilk sıraya koydukları göz önünde bulundurulduğunda bu sonuç diğeri ile örtüşmektedir. 
H. Özdemir - E. Akagün Ergin - M. S. Avc1 13/2 (2021) 1751-1763

Tablo 3. En Sevilen ve Saygı Duyulan Ünlü Antrenör/Teknik Adam/Sporcular’a Göre Sıralama

\begin{tabular}{lll}
\hline Siralama & Antrenör/Teknik Adam/ Sporcu & \% \\
\hline $\mathbf{1}$ & Fatih Terim & 21,5 \\
$\mathbf{2}$ & Cristiano Ronaldo & 7,8 \\
$\mathbf{3}$ & Lionel Messi & 6 \\
\hline
\end{tabular}

Araştırmada, atletik yıldız gücü faktörlerinin (profesyonel güvenilirlik, sempatik kişilik, atletik uzmanlık, sosyal çekicilik ve karakteristik tarz) Y kuşağı bireylerinin genel tüketimlerini ne düzeyde yormadığını belirlemek amacıyla çoklu doğrusal regresyon analizi kullanılmış, modeldeki beş bağımsız değişken Stepwise metodu ile analiz edilmiş ve analiz sonucunda iki değişken (sempatik kişilik ve karakteristik tarz) model dışı bırakılmış, model üç bağımsız değişken ile test edilmiştir. Analizden elde edilen değerler doğrultusunda üçüncü modelin istatistiki olarak anlamlı olduğu sonucuna varılmıştır (sign $\leq 0,05, F=193,764$ ). Buna göre, profesyonel güvenilirlik, atletik uzmanlık ve sosyal çekicilik değişkenlerinin $Y$ kuşağı bireylerinin genel tüketimlerini etkilediğini söylemek mümkündür.

Regresyon modellerindeki otokorelasyon hatalarını görmek için, Durbin-Watson testi kullanılmış ve elde edilen DW değerine göre modelde otokorelasyon olmadığı saptanmıştır (DW=2,04). Çoklu regresyon denkleminin yorumu, bağımsız değişkenlerin kuvvetli bir şekilde ilişkili olmaması varsayımına bağlıdır. Bu varsayımın bozulması, yani bağımsız değişkenler arasında bir ya da daha fazla doğrusal bağlantının olması çoklu bağlantı (multicollinearity) sorununu gündeme getirir.

Çoklu bağlantının varlığının belirlenmesinde kullanılan yöntemlerden biri de VIF olarak adlandırılan "Varyans Şişme Değeri" dir ve bu değerin 5 ya da 10'un üzerinde olması güçlü çoklu bağlantının göstergesi olarak kabul edilir (Alpar, 2013: 534-538). Hesaplanan VIF ve tolerans değerlerine göre, bağımsız değişkenler arasında çoklu bağlantı (multicollinearity) probleminin olmadığı görülmektedir (Tablo 4).

Tablo 4: H1 Hipotezine İlişkin Çoklu Doğrusal Regresyon Analizi Sonuçları

\begin{tabular}{|c|c|c|c|c|c|c|}
\hline \multicolumn{5}{|c|}{ Model } & \multicolumn{2}{|c|}{$\begin{array}{l}\text { Çoklu Bağlantı } \\
\text { İstatistikleri }\end{array}$} \\
\hline \multirow[t]{2}{*}{1} & (Sabit) & & 26,473 & ,000 & Tolerans & VIF \\
\hline & $\begin{array}{l}\text { Profesyonel } \\
\text { Güvenilirlik } \\
\text { (Sabit) }\end{array}$ & ,713 & 21,529 & $\begin{array}{l}, 000 \\
, 000\end{array}$ & 1,000 & 1,000 \\
\hline \multirow{2}{*}{2} & $\begin{array}{l}\text { Profesyonel } \\
\text { güvenilirlik }\end{array}$ & 690 & 21,767 & ,000 & ,989 & 1,011 \\
\hline & $\begin{array}{l}\text { Atletik } \\
\text { Uzmanlık } \\
\text { (Sabit) }\end{array}$ & ,219 & 6,917 & ,000 & ,989 & 1,011 \\
\hline \multirow{3}{*}{3} & $\begin{array}{l}\text { Profesyonel } \\
\text { Güvenilirlik }\end{array}$ & 683 & 21,726 & ,000 & ,984 & 1,016 \\
\hline & $\begin{array}{l}\text { Atletik } \\
\text { Uzmanlık }\end{array}$ & ,178 & 5,244 & ,000 & 844 & 1,184 \\
\hline & Sosyal Çekicilik & ,108 & 3,176 & ,002 & 845 & 1,183 \\
\hline \multicolumn{7}{|c|}{ a. Bağımlı Değişken: Genel Tüketim } \\
\hline
\end{tabular}

Değişkenler arası ilişkilere bakıldığında $(R=0,50)$, değişkenler arasında pozitif ve orta kuvvette bir ilişkinin var olduğunu söylemek mümkündür. Determinasyon katsayına göre ise $\left(R^{2}=0,25\right)$, yıldız gücü faktörlerinin tüketicilerin genel tüketimleri üzerindeki olumlu etkisinin \%25 olduğu görülmektedir. Beta katsayıları 


\section{H. Özdemir - E. Akagün Ergin - M. S. Avc1 13/2 (2021) 1751-1763}

incelendiğinde, katılımcıların genel tüketimlerine en çok etki eden faktörün "atletik uzmanlık faktörü" olduğu belirlenirken $(\beta=0,165)$, en az etki eden faktörün ise "sempatik kişilik faktörü" olduğu $(\beta=0,06)$ belirlenmiştir $\left(R=0,50 \quad R^{2}=0,25 F=30,756\right.$ Sign: 0,000). Tablo 4'te Stepwise çoklu doğrusal regresyon analizinin üç aşamada tamamlandığı ve varyansa katkıları bakımından profesyonel güvenilirlik, atletik uzmanlık ve sosyal çekicilik faktörlerinin Y kuşağı bireylerinin genel tüketimlerinde önemli yordayıcılar olduğu görülmektedir. Değişkenler arası ilişkilere bakıldığında $(R=0,75)$, değişkenler arasında pozitif ve kuvvetli bir ilişkinin var olduğunu söylemek mümkündür. Determinasyon katsayına göre ise $\left(R^{2}=0,56\right)$, yıldız gücü faktörlerinin tüketicilerin genel tüketimleri üzerindeki olumlu etkisinin \%56 olduğu görülmektedir. Beta katsayıları incelendiğinde, katılımcıların genel tüketimlerine en çok etki eden faktörün “atletik uzmanlık faktörü" olduğu belirlenirken $(\beta=0,165)$, en az etki eden faktörün ise "sempatik kişilik faktörü" olduğu $(\beta=0,06)$ belirlenmiştir $\left(\mathrm{R}=0,50 \quad \mathrm{R}^{2}=0,25 \mathrm{~F}=30,756\right.$ Sign:0,000).

Tablo 5. H2 Hipotezine İlişkin Çoklu Doğrusal Regresyon Analizi Sonuçları

\begin{tabular}{|c|c|c|c|c|c|c|}
\hline \multicolumn{2}{|c|}{ Model } & \multirow[t]{2}{*}{ Beta } & \multirow[t]{2}{*}{$\mathbf{t}$} & \multirow[t]{2}{*}{ Sig. } & \multicolumn{2}{|c|}{$\begin{array}{l}\text { Çoklu Bağlantı } \\
\text { İstatistikleri }\end{array}$} \\
\hline & & & & & Tolerans & VIF \\
\hline \multirow[t]{3}{*}{1} & (Sabit) & & 9,865 & ,000 & & \\
\hline & Atletik Uzmanlık &, 526 & 13,103 & , 000 & 1,000 & 1,000 \\
\hline & & & 7,057 & ,000 & & \\
\hline \multirow[t]{4}{*}{2} & (Sabit) & & & & & \\
\hline & Atletik.Uzmanlık & ,411 & 9,668 & ,000 & ,820 & 1,220 \\
\hline & Karakteristik Tarz & ,272 & 6,398 & ,000 & 820 & 1,220 \\
\hline & & & 6,072 & ,000 & & \\
\hline \multirow[t]{5}{*}{3} & (Sabit) & & & & & \\
\hline & Atletik Uzmanlık & ,317 & 6,635 & ,000 & 627 & 1,596 \\
\hline & Karakteristik Tarz & ,2 & 4,539 & , 000 & 707 & 1,415 \\
\hline & Sempatik Kişilik & ,205 & 4,038 & ,000 & ,555 & 1,802 \\
\hline & & & 5,153 & ,000 & & \\
\hline \multirow[t]{5}{*}{4} & (Sabit) & & & & & \\
\hline & Atletik Uzmanlık & ,262 & 5,138 & ,000 &, 543 & 1,843 \\
\hline & Karakteristik Tarz & ,173 & 3,772 & , 000 & 669 & 1,494 \\
\hline & Sempatik Kişilik & ,167 & 3,223 & ,001 &, 522 & 1,916 \\
\hline & Sosyal Çekicilik & 152 & 2,979 & ,003 &, 538 & 1,858 \\
\hline
\end{tabular}

a. Bağımlı Değişken: Spesifik.Tüketim

Model 4: $\mathrm{R}=0,611 \quad \mathrm{R}^{2}=0,374 \quad \mathrm{~F}=66,340 \quad$ Sign $=0,000 \quad \mathrm{DW}=\mathbf{1 , 9 7}$

Araştırmanın ikinci hipotezinde yıldız gücü faktörlerinin $Y$ kuşağı bireylerin spesifik tüketimleri üzerindeki etkileri analiz edilmiştir. Analiz sonucunda $\mathbf{H}_{2}$ hipotezi kabul edilmiştir ( $R=0,611 \quad \mathrm{R}^{2}=0,37 \quad F=66,340$ Sign=0,000). H1 hipotezinde olduğu gibi, elde edilen DW değerine göre modelde otokorelasyon olmadığ1 saptanmış (DW=1,97), VIF ve tolerans değerlerine göre ise, bağımsız değişkenler arasında çoklu bağlantı (multicollinearity) probleminin olmadığ 1 belirlenmiştir. Tablo 5 'te Stepwise çoklu doğrusal regresyon analizinin $\mathrm{H} 2$ hipotezi için dört aşamada tamamlandığı ve varyansa katkıları bakımından atletik uzmanlık, karakteristik tarz, sempatik tarz ve sosyal çekicilik faktörlerinin $Y$ kuşağ 1 bireylerinin spesifik tüketimlerinde önemli yordayıcılar olduğu görülmektedir. Değişkenler arası ilişkilere bakıldığında Model 4 için, R değerine göre $(0,61)$, değişkenler arasında pozitif ve orta kuvvette bir ilişki var olduğu, determinasyon katsayısına göre ise $(0,37)$, yıldız gücü faktörlerinin bireylerin spesifik tüketimleri üzerindeki değişliklerin \%32'sini açıladığ 1 görülmektedir. Beta katsayıları incelendiğinde, katılımcıların genel tüketimlerine en çok etki eden faktörün, genel tüketimde olduğu gibi "atletik uzmanlık faktörü" olduğu görülmektedir $(\beta=0,262)$.

$\mathrm{H}_{3}$ hipotezinde ise, atletik yıldız gücü etkisinin cinsiyetlere göre fark gösterip göstermediği incelenmiştir. Yapılan T-Testi analizine göre $\mathbf{H}_{3}$ hipotezi kabul edilmiştir (sign;0,000). Buna göre yıldız gücü etkisinin $\mathbf{Y}$ kuşağı kadın ve erkek tüketiciler üzerinde anlamlı bir farklılık gösterdiği görülmektedir. Ortalama değerlere 


\section{H. Özdemir - E. Akagün Ergin - M. S. Avc1 13/2 (2021) 1751-1763}

bakıldığında erkek tüketicilerin $(\bar{X}=3,29)$, kadın tüketicilere göre $(\bar{X}=3,09)$ atletik yıldız gücünden daha fazla etkilendiklerini söylemek mümkündür.

Araştırmanın son hipotezinde ise, atletik yıldız gücü etkisinin yaş gruplarına göre farkı incelenmiştir. Yapılan ANOVA analizi sonucunda $\mathbf{H}_{4}$ Hipotezi reddedilmiş (sign: 0,152) ve yıldız gücü etkisinin katılımcılarının yaşlarına göre farklılaşmadığı sonucuna varılmıştır.

\section{Sonuç ve Tartışma}

"Millennials" olarak da adlandırılan Y kuşağı; nüfus yoğunlukları, tüketim güçleri ve çevrelerindeki diğer tüketicilerin satın alma kararlarını etkileme yetenekleri nedeniyle, günümüzde pazar araştırmacıları, reklamcilar, markalar ve işletmeler için oldukça önemli bir pazar segmentidir. Spor yapmayı seven, sporculara hayranlık ve saygı duyan bu kuşak için ünlü ve yıldız sporcuları reklamlarda marka yüzü olarak kullanmak, günümüzde sıklıkla başvurulan etkili bir strateji olarak karşımıza çıkmaktadır. Bu noktadan hareketle, spor pazarlamacıları da, günümüzün en büyük ve etkili tüketici kuşağı kabul edilen Y kuşağının ihtiyaçlarını ve isteklerini dikkate alan stratejiler kullanarak, bu tüketici grubundan faydalanma çabasındadır. Ancak yine de bu kuşağın tüketim kararları ve yıldız gücünün etkisi üzerine yapılan çalışmaların sınırlı olduğu da görülmektedir. Buna ek olarak, çeşitli çalışmalarda yıldız sporcuların tüketiciler üzerindeki etkilerine dair bileşenlerin birbirlerinden bağımsız olarak değerlendirildiği ve reklamlarda kullanılan yıldız sporcuların ve yıldız gücü etkisinin tüketicileri ne ölçüde etkilediklerine dair bölgesel bir çalışmanın da eksikliği olduğu görülmektedir. Bu eksiklikten yola çıkarak, bu araştırmada "yıldız gücü faktörleri" olarak bilinen; profesyonel güvenilirlik, sempatik kişilik, atletik uzmanlık, sosyal çekicilik ve karakteristik tarz faktörlerinin $\mathrm{Y}$ kuşağı bireylerinin genel ve spesifik tüketimleri üzerindeki etkilerini ortaya koymak hedeflenmiş, ek olarak, yıldız gücü etkisinin cinsiyet ve yaş demografik değişkenleri ile ilişkileri de incelenmiştir.

Braunstein ve Zhang (2005), tarafından geliştirilen ve yıldız gücünü en iyi açıklayan dört ana teorinin (Source Credibility Model, Source Attractiveness Model, Meaning Transfer Model Ve Product Match-Up Hypothesis) bir kombinasyonu olarak oluşturulan SASP (Athletic Star Power) ölçeği yardımıyla Y kuşağı tüketicilerin genel ve spesifik tüketim kararlarının analiz edildiği bu çalışmada, yazarların star gücü bileşenleri olarak belirledikleri beş ana faktör tüketim kararları açısından incelenmiştir. Yapılan analizler ve değerlendirmeler sonucunda; star gücü bileşenleri olarak kabul edilen profesyonel güvenilirlik, sempatik kişilik, atletik uzmanlık, sosyal çekicilik ve karakteristik tarz faktörlerinden profesyonel güvenilirlik, atletik uzmanlık ve sosyal çekicilik değişkenlerinin $Y$ kuşağı bireylerinin genel tüketimlerini etkilediğini; atletik uzmanlık, karakteristik tarz, sempatik tarz ve sosyal çekicilik faktörlerinin ise $Y$ kuşağının spesifik tüketimlerinde önemli yordayıcılar olduğu sonucuna varılmıştır.

Araştırmaya ana kaynak olarak seçilen ve ölçeklerinden yararlanılan Braunstein ve Zhang (2005) çalışmaları sonucunda, yıldız gücü faktörlerinin Y kuşağı tüketicilerin genel ve spesifik tüketim kararların etkiledikleri sonucuna varmışlardır. Buna ek olarak, Khabiri vd. (2017) de, çalışmalarında yıldız gücünün tüm bileşenleri ile tüketicilerin tutum ve satın alma niyeti arasında önemli bir ilişki olduğunu ortaya koymuşlardır. Bu araştırmadaki sonuçlar da, yazarların çalışma sonuçları ile örtüşmektedir. Ancak araştırmanın diğer hipotezinde incelenen cinsiyet değişkeni ile yıldız gücü etkisi ilişkisinin, literatürdeki diğer çalışmalardan farklılaştığı görülmektedir. Bu araştırmada erkek tüketicilerin $(\bar{X}=3,29)$, kadın tüketicilere göre $(\bar{X}=3,09)$ atletik yıldız gücünden daha fazla etkilendikleri görülürken, Bush vd. (2004), çalışmalarının sonucunda ünlü sporcuların, kadınları belirli markaları satın almaları konusunda erkeklerden daha fazla etkilediği sonucuna varmışlardır. Braunstein ve Zhang'a (2005) ise, Y kuşağı tüketicilerin cinsiyet farklılıkları dikkate alındığında, marka yüzü olan sporcuların çekicilik ve uzmanlık açısından kadın katılımcılar üzerinde daha etkili olduğunu belirlemişlerdir. Dusenberg vd.'e göre ise (2016), kadın tüketiciler, en sevdikleri sporcuların desteklediği bir marka veya ürün hakkında daha olumlu görüş bildirmektedirler ve cinsiyet tüketicilerin satın alma niyetini etkileyen önemli bir unsurdur. Cinsiyetler açısından farklılık olmasına rağmen, araştırmada yıldız gücü etkisinin yaş gruplarına göre farklılaşmadığ tespit edilmiştir.

Star stratejisi pazarlama iletişimi elemanlarının oluşturduğu stratejiyi ve hedefleri gerçekleştirmek yönünde reklamın hedef kitlesi ile nasıl buluşacağını belirlemektedir (Ortancıl, 2021). Bu çalışmanın ana çıktısı olarak da Y kuşağı tüketicilerin tüketim kararları seçilmiştir. Tüketim kararı, tüketici davranışları açısından en önemli ölçümlerden birisi olarak araştırmacılar tarafından sıklıkla tercih edilmektedir. Her açıdan güçlü ve 


\section{H. Özdemir - E. Akagün Ergin - M. S. Avcr 13/2 (2021) 1751-1763}

faklı olan bu kuşağın ihtiyaçlarını ve arzularını anlamak, bu kuşaktaki bireylerin tüketim kararlarına etki eden faktörleri iyi analiz edebilmek, firmalar açısından oldukça önemli ve faydalı sonuçlar doğuracaktır. Buna ek olarak, içerdiği sonuçlar açısından bu araştırmanın, reklamlarında yıldız sporcuları kullanmayı tercih eden markalar ve işletmeler için de fayda sağlayacağı düşünülmektedir. "Yıldız Gücü” kavramının ve yıldız gücü faktörlerinin Y kuşağının tüketim kararları üzerindeki etkilerini inceleyen spor pazarlaması araştırmalarının literatürde çok fazla olmaması nedeniyle, bu önemli tüketici grubunu ve atletik yıldız gücü kavramını birlikte ele alan bu çalışmayı yapma ihtiyacı doğmuş, literatüre bu konuda katkı sağlamak hedeflenmiştir.

Bu alanda daha fazla araştırma yapılmasının, yıldız gücü etkisinin farklı kuşaklar üzerinde de incelenmesinin ve daha geniş örneklemlerle çalışılmasının markalar ve firmalara daha etkili faydalar sağlayacağı ve mevcut literatürü zenginleştireceği düşünülmektedir. $\mathrm{Bu}$ çalışma $\mathrm{Y}$ kuşağının yalnızca tüketim kararlarına odaklanmıştır. Gelecekte yapılacak çalışmalarda, yıldız gücü bileşenlerinin tüketicilerin markaya karşı tutumlarına etkisinin de incelenmesi, markalara; konumlandırma, imaj yaratma ve markaya karşı olumlu tutum oluşturma konularında katkılar sağlayabilecektir.

\section{KAYNAKÇA}

Alpar, R. (2013). Çok Değiş̧kenli İstatistiksel Yöntemler (4. Baskı), Ankara, Detay Yayıncılık.

Bennett, G., Henson, R.K and Zhang, J. (2003). Generation Y's perceptions of the action sports industry segment. Journal of Sport Management, 17(2), 95-115.

Bennett, G., and Henson, R.K. (2003). Perceived status of the action sports segment among college students. International Sports Journal. 7(1), 124-39.

Braunstein, J.R. (2006). Influence of product-endorser match-up on consumer's purchase intentions of (nonsport) endorsed products (PhD Thesis). The Graduate School of The University of Florida, Florida.

Braunstein, J.R. and Zhang, J.J. (2005). Dimensions of athletic star power associated with generation y sports consumption. International Journal of Sports Marketing and Sponsorship, 6 (4), 37-62.

Bush, A.J, Craig A.M., and Bush, V.D. (2004). Sports celebrity influence on the behavioral intentions of generation Y. Journal of Advertising Research, 44(1), 108-118.

Bush, V.D., Bush, A.J., Clark, P.W., \& Bush, R. (2005). Girl power and word-of-mouth behavior in the flourishing sports market. The Journal of Consumer Marketing, 22 (4/5), 257-64.

Choi, S.M., Lee, W. and Kim, H. (2005). Lessons from the rich and famous: a cross-cultural comparison of celebrity endorsement in advertising. Journal of Advertising, 34(2), 85-98.

Çam, M.S. (2016). Her ünlü star mıdır? Reklamlarda ünlü kullanımı üzerine bir değerlendirme. Dumlupınar Üniversitesi Sosyal Bilimler Dergisi, 2016 Özel Sayısı, 162-173.

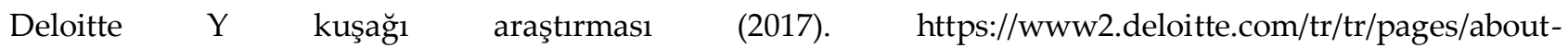
deloitte/articles/millennialsurvey-2017.html\# (Erişimtarihi: 19 Ocak 2019).

Dix, S., Phau, I. and Pougnet, S. (2010). "Bend it like Beckham": The influence of sports celebrities on young adult consumers. Young Consumers, 11(1), 36-46.

Dusenberg, N., Almeida, V. and Amorim, J. (2016). The influence of sports celebrity credibility on purchase intention: the moderating effect of gender and consumer sports-involvement. Brazilian Business Review, Fucape Business School, 13 (Special I), 1-21.

Dugalıć, S. and Lazarević, S. (2016). The impact of celebrity athlete endorsement on purchasing habits. Facta Universitatis: Series Physical Education and Sport. 14(3), 435-446.

Erdoğan, B. Z. (1999) Celebrity endorsement: a literature review. Journal of Marketing Management. 15:4, 291314.

Gültekin, G. (2012). Televizyon reklamlarında spor teması kullanımının marka tutumu üzerindeki etkisi, (Yayımlanmamış yüksek lisans tezi). Selçuk Üniversitesi Sosyal Bilimler Enstitüsü, Konya.

Holton, L. (2000). The surfer in the family. American Demographics, 22(4), 34-36.

Howard, A. (1979). More than just a passing fancy. Advertising Age, 50, July 30, S-2. 


\section{H. Özdemir - E. Akagün Ergin - M. S. Avcr 13/2 (2021) 1751-1763}

James, J.D. and Ridinger, L.L. (2002). Female and male sport fans: a comparison of sport consumption motives. Journal of Sports Behavior, 25(3), 260-71.

Janoff, B. (2004). The world not according to Kobe. Brandweek, 45(2), 20.

Karaman, F. and Baş, M. (2019). Üç Büyüklerin Taraftar Magazalarının Dijital Pazarlama Kanalları Kapsamında Incelenmesi. 23. MilletlerArası Türk Kooperatifçilik Kongresi, 407-419.

Katırcı, H. and Yüce, A. (2016). Dergi reklamlarında spor ünlüsü kullanımı: GQ Türkiye 127 örneği. The Turkish Online Journal of Design, Art and Communication- TOJDAC, 6(2), 128-136.

Kaur, H. and Anand, S. (2018). Segmenting generation Y using the big five personality traits: understanding differences in fashion consciousness, status consumption and materialism. Young Consumers, 19(4), 382-401.

Khabiri, M., Sajjadi, N., Hamidi, M and Bashiri, M. (2017). The effect of Iranian athletes' endorsement on attitude and purchase intention of customers and developing a model. Sport Physiology \& Management Investigations, 9(1), 91-111.

Kuyucu, M. (2017). Y kuşağı ve teknoloji: y kuşağının iletişim teknolojilerini kullanım alışkanlıkları. Gümüşhane Üniversitesi İletişim Fakültesi Dergisi, 5(2), 845-872.

Lear, K.E., Runyan, R.C. and Whitaker, W.H. (2009). Sports celebrity endorsements in retail products advertising. International Journal of Retail and Distribution Management, 37(4), 308-321.

Lewis, M. and Yoon, Y. (2018). An empirical examination of the development and impact of star power in major league baseball. Journal of Sports Economics, 19(2), 155-187.

Li, B., Liu, Y., Wang, J., Scott, O. and Stokowski, S. (2019). Does star power boost soccer match attendance? Empirical evidence from the Chinese soccer league. International Journal of Sport Finance, 14(2), 97-109.

Magnini, V.P., Garcia, C. and Honeycutt, E.D. (2010). Identifying the attributes of an effective restaurant chain endorser. Cornell Hospitality Quarterly, 51(2), 238-250.

Marlatt, A. (1999). Yen for e-tail. Internet World, 5(26), 39-40.

McCracken, G. (1989). Who is the celebrity endorser? cultural foundations of the endorsement process. Journal of Consumer Research, 16(3), 310-332.

McCormick, K. (2018). Impact of athletic star power on product consumption. International Journal of Sports Marketing and Sponsorship, 19(3), 306-326.

Ortancil, G. (2021). Reklamlarda Star Stratejisi http://danismend.com/kategori/altkategori/reklamlarda-starstratejisi/ (Erişim tarihi: 17 Nisan 2021).

Rahman, M. (2011). The burdens of the flesh: star power and the queer dialectic in sports celebrity. Celebrity Studies, 2(2), 150-163.

Rein, I., Kotler, P. \& Stoller, M. (1997). High visibility: The making and marketing of professionals into celebrities. Chicago, NTC Business Books.

Renton, K. (2009). Impact of Athletic Endorsements on Consumers Purchase Intentions (PhD Thesis). The Florida State University, Florida.

Sencer, M. (1989). Toplumbilimlerinde yöntem (GözdenGeçirilmiş3.Baskı). İstanbul, Beta Basım.

Solak, B. B. (2016). Televizyon reklamlarında ünlü kullanımının satın alma davranışı üzerine etkisi. Akdeniz Üniversitesi İletişim Fakültesi öğrencilerine yönelik araştırma. Gümüşhane Üniversitesi İletişim Fakültesi Elektronik Dergisi, 4(1), 253-278.

Thomaselli, R. (2008). With no ring, James is still no Jordan. Advertising Age, 79(39), 4.

Valaei, N. and Nikhashemi, S.R. (2017). Generation Y consumers' buying behavior in fashion apparel, industry: a moderation analysis. Journal of Fashion Marketing and Management, 21(4), 523-543.

Woods, L. (2017). Why Nike uses endorsements \& sponsorships? https://bizfluent.com/13636879/why-nikeuses-endorsements-sponsorships. (Erişim tarihi: 08/04/2021).

Yang, W. (2018). Star power: the evolution of celebrity endorsement research. International Journal of Contemporary Hospitality Management, 30(1), 389-415. 